\title{
Effect of dietary lysine level on lipogenesis in broilers
}

\author{
ML Grisoni 1*, G Uzu 2, M Larbier 1, PA Geraert 1 \\ 1 INRA, Station de Recherches Avicoles, 37380 Nouzilly; \\ ${ }^{2}$ Rhône-Poulenc Animal Nutrition, 03600 Commentry, France
}

(Received 7 February 1991; accepted 16 September 1991)

\begin{abstract}
Summary - From 3-7 weeks of age, male and female broilers were fed ad libitum on 1 of the 8 experimental diets. These diets were isoenergetic $(13.6 \mathrm{~kJ} / \mathrm{kg})$ and isoproteic $(186 \mathrm{~g} / \mathrm{kg})$ and provided 7 to $14 \mathrm{~g} / \mathrm{kg}$ lysine. The growth performances, the abdominal fat proportion and hepatic malic enzyme activity (malate dehydrogenase with decarboxylating EC 1.1.1.40) were measured. All parameters varied when dietary lysine concentration was increased from 7 to 9 or to $11 \mathrm{~g} / \mathrm{kg}$. The lysine requirement in the finishing period for minimum abdominal fat proportion was higher than for minimum feed conversion ratio, itseful higher than for maximal growth rate. Malic enzyme activity varied with abdominal fat proportion, and this variation could explain the reduction in fatness. However, an excess of lysine did not amplify the reduction of fat deposit.
\end{abstract}

lysine / broiler / abdominal fat / lipogenesis / malic enzyme

Résumé - Influence de la concentration alimentaire de lysine sur la lipogenèse chez le poulet de chair. Des poulets de chair, mâles et femelles, sont nourris ad libitum entre 3 et 7 semaines d'âge avec l'un des 8 régimes expérimentaux. Ces aliments sont isoénergétiques $(13,6 \mathrm{~kJ} / \mathrm{kg})$ et isoprotéiques (186 g/kg) et apportent entre 7 et $14 \mathrm{~g} / \mathrm{kg}$ de lysine. Les performances de croissance, la proportion de gras abdominal et l'activité hépatique de l'enzyme malique (malate déshydrogénase avec décarboxylation EC 1.1.1.40) sont mesurées.

Tous ces paramètres varient avec l'augmentation de lysine dans l'aliment de 7 à 9 ou $11 \mathrm{~g} / \mathrm{kg}$. Le besoin en lysine en période de finition pour une proportion minimale de gras abdominal apparaît supérieur à celui nécessaire à l'obtention du meilleur indice de consommation. De même, un apport supplémentaire de lysine est nécessaire si on prend en compte l'indice de consommation au lieu de la vitesse de croissance. L'activité hépatique de l'enzyme malique varie parallèlement à la proportion de gras abdominal, expliquant ainsi une réduction de lipogenèse avec l'augmentation de lysine dans l'aliment. Toutefois, un excès de lysine ne diminue pas l'engraissement au-delà d'une certaine limite.

lysine / poulet / gras abdominal / lipogenèse / enzyme malique

* Correspondence and reprints 


\section{INTRODUCTION}

It is generally admitted that body composition of chickens depends on bird genotype and the environmental and nutritional conditions. In particular, a reduction in fatness was often observed when a dietary excess of protein was given by using diets containing more than $180 \mathrm{~g}$ of proteins per $\mathrm{kg}$ (AEC, 1976; Fisher, 1984; Pesti and Fletcher, 1984; Leenstra, 1986; Nir et al, 1988). In some experiments it was shown that the addition of methionine or lysine in hypoproteic diets reduced the abdominal fat proportion (Larbier and Leclercq, 1980; Uzu, 1982).

The study reported here was conducted to observe the influence of widely different concentrations of lysine from deficit to excess in a finisher diet, with the object of measuring growth performances and fat deposit in the abdominal cavity.

Furthermore, lipogenesis was studied by the measuring malic enzyme activity (decarboxylating malate dehydrogenase E.C.1.1.1.40) which plays a major role in fatty acid biosynthesis in birds (Yeh and Leveille, 1969; Leveille et al, 1975; Chang and Hsu, 1977).

\section{MATERIAL AND METHODS}

\section{Animals and diets}

2560 1-day-old Vedette (ISA-France) chickens, sex-separated, were allotted to 24 floor-pens and fed ad libitum until 49 days of age. During the first 3 weeks, they received a standard starter diet containing $220 \mathrm{~g} / \mathrm{kg}$ of crude protein (CP) and $13 \mathrm{~kJ}$ ME per $\mathrm{kg}$. At 22 days of age, after an overnight fast, males and females were weighed individually and uniformly distributed between 8 experimental groups per sex. Each treatment was applied to 4 replicate pens of 40 broilers.
The experimental finisher diets were distributed up to 49 days of age. They were prepared from a basal diet supplemented with L-lysine $\mathrm{HCl}$ to provide from $7-14 \mathrm{~g} / \mathrm{kg}$ of total lysine (table 1). The lysine content of the basal diet was measured using an auto analyzer (Biotronik, amino acid analyser LC 5000, Germany) after $24 \mathrm{~h}$ hydrolysis with $6 \mathrm{M}$ aqueous $\mathrm{HCl}$ at $115^{\circ} \mathrm{C}$. All diets were isoproteic (186 $\mathrm{g}$ of crude protein per $\mathrm{kg}$ ) and isoenergetic (13.6 $\mathrm{kJ}$ of apparent metabolisable energy per $\mathrm{kg}$ ). They were pelleted.

At 49 days of age, after another overnight fast, chickens were weighed individually. 52 males per dietary group (ie 13 per pen) whose weights were close to the mean weight of the pen were chosen. Among these birds, 40 per group were slaughtered. The abdominal fat was excised and weighed. The ready-to-cook carcass was dressed and weighed. The other male

Table I. Composition and analysis of the basal diet.

\section{Constituents}

$\begin{array}{lr}\text { Ingredients }(\mathrm{g} / \mathrm{kg}) & 671 \\ \text { Maize } & 100 \\ \text { Maize gluten meal } & 160 \\ \text { Soya meal } & 30 \\ \text { Maize oil } & 16 \\ \text { Dicalcium phosphate } & 12 \\ \text { Calcium carbonate } & 4 \\ \text { Salt } & 6.5 \\ \text { Vitamins and trace elements }{ }^{*} & \\ & \\ \text { Analysis (g/kg) } & 13.6 \\ \text { Apparent metabolisable energy }(\mathrm{kJ} / \mathrm{kg}) & 186 \\ \text { Protein } & 7 \\ \text { Lysine } & 8.3 \\ \text { Sulphur amino acids } & 7 \\ \text { Threonine } & 8.9 \\ \text { Calcium } & 4 \\ \text { Available phosphorus } & \end{array}$

* As used by Larbier and Leclercq (1980). 
chickens (12 per group) were fed again and slaughtered 1 day later. They were exsanguinated, the liver was immediately dissected, weighed and frozen in liquid nitrogen. It was stored at $-20{ }^{\circ} \mathrm{C}$ until required for enzymatic analysis.

\section{Enzyme assays}

Each liver was ground and a sample $(\approx 5 \mathrm{~g})$ was homogenised in TMNSH buffer (Tris- $\mathrm{HCl} 10$ $\mathrm{mM}, \mathrm{pH} 7.4, \mathrm{MgCL}_{2} 10 \mathrm{mM}, \mathrm{NH}_{4} \mathrm{Cl} 60 \mathrm{mM}$ and 3-mercaptoethanol $7 \mathrm{mM}$ ) with a PotterElvehjem $(1 / 1, w / v)$, at ice-bath temperatures. The homogenates were centrifuged at $20000 \mathrm{~g}$ for $90 \mathrm{~min}$, at $4^{\circ} \mathrm{C}$ and under vacuum. The resulting supernatant fraction was used for the enzymatic assay.

Malic enzyme activity was measured according to Ochoa's method (1955). The results were then expressed in units of enzyme activity defined as the amount of enzyme which catalysed the conversion of $1 \mu \mathrm{mol}$ of substrate per min and at $37^{\circ} \mathrm{C}$.

\section{Statistical treatment}

The influence of dietary lysine content on growth performances, body composition and malic enzyme activity in liver was estimated by analysis of variance. Significant differences between means of weight gain, feed conversion ratio, abdominal fat proportion or of hepatic malic enzyme activity were determined according to Duncan's test (1955).

\section{RESULTS}

The mortality rate was very low and did not exceed $2 \%$. There was no significant difference between treatments. The weight gain of broilers increased significantly (+ 7\%) when the dietary lysine content was increased from 7 to $9 \mathrm{~g} / \mathrm{kg}$, but it was not affected by higher lysine levels (table II).
Feed intake did not change with lysine concentration in diets. However, feed conversion ratio decreased from 2.28 to 2.03 for animal fed diets with increased lysine level from 7 to $10 \mathrm{~g} / \mathrm{kg}$.

On the other hand, growth performances differed between sexes. The male birds showed higher weight gain, food consumption and lower feed conversion ratio than female birds. The effect of sex on weight gain interacted with that of diet.

The concentration of lysine in the diet significantly modified the body composition of male chickens (table III). The abdominal fat proportion was reduced from 3.97 to $2.63 \%$ of live weight, or from 6.42 to $4.04 \%$ of carcass weight, when lysine level increased from 7 to $11 \mathrm{~g} / \mathrm{kg}$ in the diet. But, no significant variation in the absolute amount of abdominal fat ( $\mathrm{g}$ ) was observed.

The dietary lysine level significantly influenced malic enzyme activity which was expressed as units per $g$ of liver (fig 1). This activity was markedly reduced $(-22 \%)$ in the chickens fed $11 \mathrm{~g} / \mathrm{kg}$ of lysine compared to the chickens given a lysine deficient diet $(7 \mathrm{~g} / \mathrm{kg})$. The values obtained were 3140 and $4014 \mathrm{U} / \mathrm{g}$ liver respectively. The weight of liver did not change with the dietary lysine level. The values varied from $54.0-65.3 \mathrm{~g}$ and were not significantly different.

In male chickens, the optimum values for weight gain, feed conversion ratio, abdominal fat proportion and malic enzyme activity were obtained by interpolations the different non-linear equations in which $x$ was the proportion of added lysine to the basal diet ( $x$ varied from $0-7 \mathrm{~g} / \mathrm{kg}$ in the diet) :

- for weight gain (3-7 wk),

$$
\begin{aligned}
y & =1665+197(1-\exp (-24.93 x)), \\
r^{2} & =0.99, \text { optimum value }=1862 \mathrm{~g}
\end{aligned}
$$


Table II. Influence of dietary lysine level on growth performances of chickens during the finishing period.

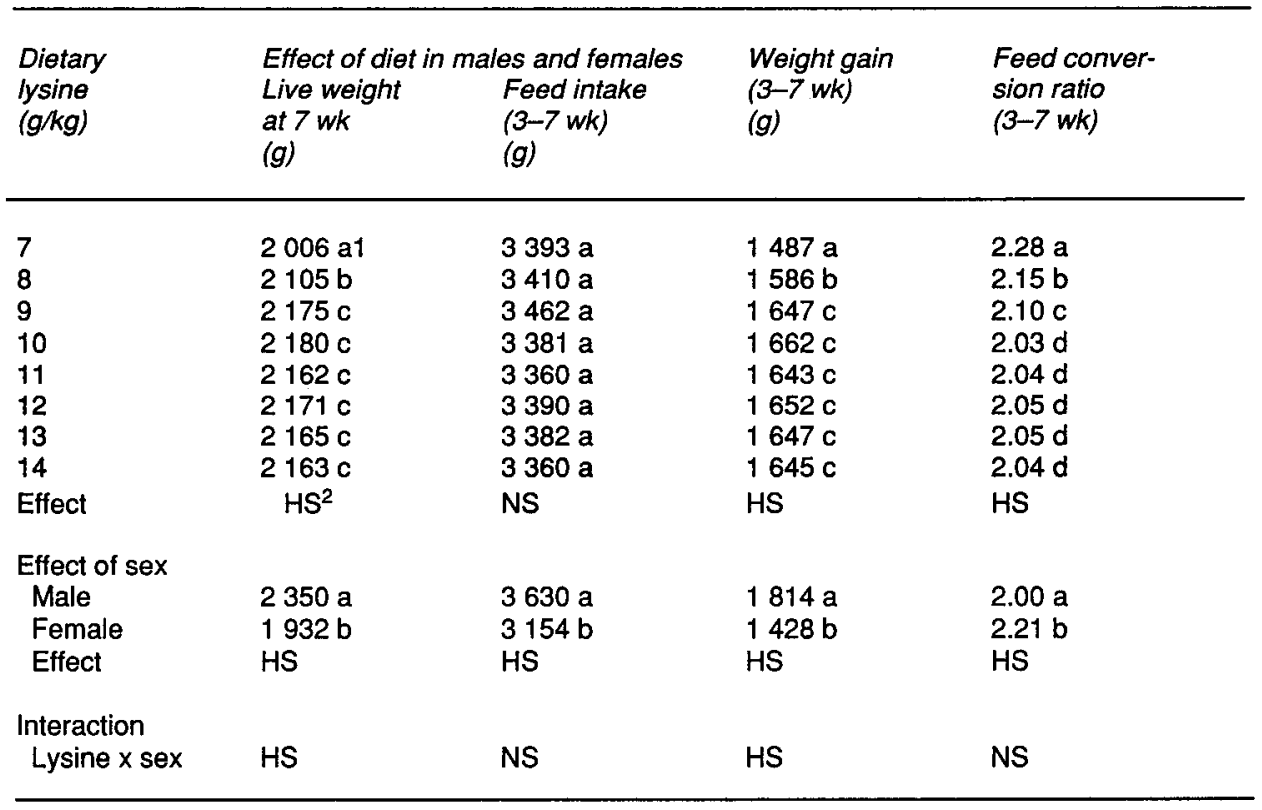

${ }^{1}$ Within each criterion, values having the same letter are not significantly different $(P<0.05) .{ }^{2} \mathrm{HS}$ : Highly signiffcant $(P<0.01)$, NS : non significant $(P>0.05)$.

Table III. Influence of dietary lysine level on body composition of 7-week-old male chickens.

\begin{tabular}{|c|c|c|c|c|c|}
\hline $\begin{array}{l}\text { Dietary } \\
\text { lysine } \\
(g / k g)\end{array}$ & $\begin{array}{l}\text { Body } \\
\text { weight } \\
\text { (g) }\end{array}$ & $\begin{array}{l}\text { Carcass } \\
\text { weight } \\
\text { (g) }\end{array}$ & $\begin{array}{l}\text { Abdominal } \\
\text { fat } \\
\text { (g) }\end{array}$ & $\begin{array}{l}A F / B W^{1} \\
(\%) \\
(\%)\end{array}$ & $\begin{array}{l}A F / C W^{2} \\
(\%) \\
(\%)\end{array}$ \\
\hline $\begin{array}{l}7 \\
8 \\
9 \\
10 \\
11 \\
12 \\
13 \\
14\end{array}$ & $\begin{array}{l}2157 a \\
2260 b \\
2403 c \\
2415 c \\
2390 c \\
2395 c \\
2404 c \\
2380 c\end{array}$ & $\begin{array}{l}1333 \mathrm{a} \\
1415 \mathrm{~b} \\
1595 \mathrm{c} \\
1540 \mathrm{c} \\
1560 \mathrm{c} \\
1545 \mathrm{c} \\
1557 \mathrm{c} \\
1550 \mathrm{c}\end{array}$ & $\begin{array}{l}85.6 \mathrm{a} \\
77.2 \mathrm{a} \\
75.3 \mathrm{a} \\
69.9 \mathrm{a} \\
63.0 \mathrm{a} \\
64.1 \mathrm{a} \\
64.1 \mathrm{a} \\
64.6 \mathrm{a}\end{array}$ & $\begin{array}{l}3.97 \mathrm{a} \\
3.41 \mathrm{~b} \\
3.13 \mathrm{c} \\
2.90 \mathrm{~cd} \\
2.63 \mathrm{~d} \\
2.68 \mathrm{~d} \\
2.67 \mathrm{~d} \\
2.71 \mathrm{~d}\end{array}$ & $\begin{array}{l}6.42 \mathrm{a} \\
5.45 \mathrm{~b} \\
4.72 \mathrm{c} \\
4.54 \mathrm{~cd} \\
4.04 \mathrm{~d} \\
4.15 \mathrm{~d} \\
4.12 \mathrm{~d} \\
4.17 \mathrm{~d}\end{array}$ \\
\hline
\end{tabular}

${ }^{1}$ Abdominal fatbody weight ratio. ${ }^{2}$ Abdominal fat/carcass weight ratio. ${ }^{3}$ Within each criterium, values with the same letter in superscript are not significantly different $(P<0.05)$. 


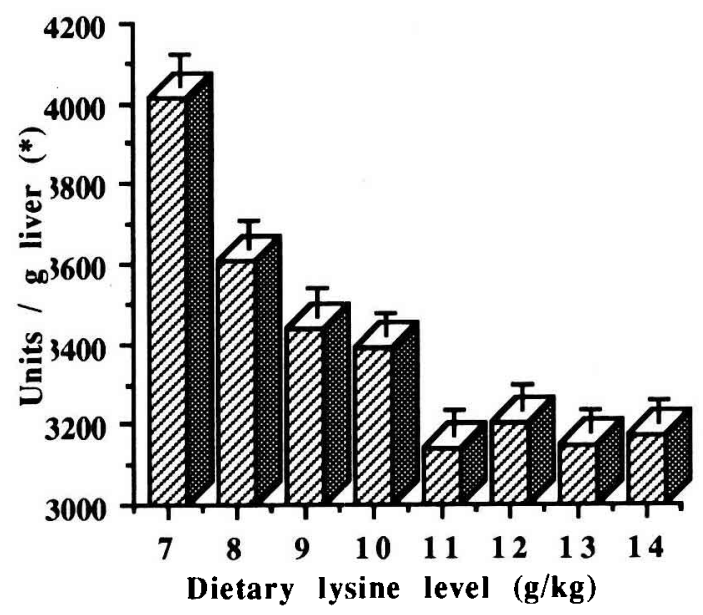

Fig 1. Effect of dietary lysine level on hepatic malic enzyme activity. (mean $\pm S E M$ of 12 fed male chickens at 7 weeks of age). *: 1 unit is the quantity of enzyme which catalysed the formation of 1 $\mu \mathrm{mol}$ of $\mathrm{NAPDH}_{2}$ per $\min$ at $37^{\circ} \mathrm{C}$.

- for feed conversion (3-7 wk),

$$
\begin{aligned}
y & =2.178-0.298(1-\exp (-18.35 x)) \\
r^{2} & =0.96, \text { optimum value }=1.88
\end{aligned}
$$

- for abdominal fat proportion at 7 weeks,

$$
\begin{gathered}
y=6.42-2.39(1-\exp (-14.64 x)) \\
r^{2}=0.95, \text { optimum value }=4.03 \% \\
\text { of carcass weight, }
\end{gathered}
$$

- and for malic enzyme activity,

$$
y=4031-885(1-\exp (-13.05 x)) \text {, }
$$

$r^{2}=0.84$, optimum value $=3146 \mathrm{U} / \mathrm{g}$ liver.

In these non linear models (used by D'Mello and Lewis, 1970), the practical $x$ value corresponding to the maximum weight gain and minimum fattening may be calculated for $y=y_{\max }-\left(0.1 \%\right.$ of $\left.y_{\max }\right)$ and $y=y_{\max }+\left(0.1 \%\right.$ of $\left.y_{\max }\right)$ respectively. In these conditions, the total concentrations of lysine in diets were $8.87,9.76,11.36$ and $11.32 \mathrm{~g} / \mathrm{kg}$ for weight gain, feed conversion, abdominal fat proportion and malic enzyme activity respectively.

These results showed that the lysine requirement of broilers depended on the measured parameter. It was higher for minimum fattening or minimum malic enzyme activity than for better feed conversion and for maximum growth rate.

\section{DISCUSSION AND CONCLUSION}

The increase in weight gain and the improvement of feed efficiency after addition of lysine to a deficient diet confirm the results obtained by Fisher (1984) and Bougon et al (1985).

The supplementation of lysine reduced the abdominal fat proportion in male chickens as noted previously by Bougon et al (1985). The close correlation between abdominal fat and carcass fat for each treat- 
ment (Scheele et al, 1981; Ehinger and Seeman, 1982; Ricard, 1983; Grisoni et al, 1990), indicates that total fatness of chicks is also affected by lysine supplementation.

The results showed that the optimum values of weight gain, feed conversion ratio and abdominal fat proportion were obtained with different lysine concentrations in the diet. In similar conditions, Nir (1984) noted that the dietary energy/protein ratio which resulted in an optimal weight gain was not necessarily the same as that needed to improve the quality of broilers.

By using non linear equations the lysine requirement for a maximum weight gain, feed efficiency and abdominal fat proportion were considered successively. Thus a slightly higher level of lysine (higher than that required for maximum growth rate) could decrease feed consumption. Nevertheless, Sibbald and Wolynetz (1986) noted that the influence of lysine level on body composition did not depend on the energy ntake. The comparison between the maximum values of the different criteria suggest, in particular, that the supplementation with lysine allowed the abdominal fat proportion to be reduced without affecting growth or feed conversion ratio. This has been recently observed for the lipid content of chilled carcasses in birds fed either L-lysine $\mathrm{HCl}$ supplemented (10.5 $\mathrm{g} / \mathrm{kg}$ total lysine) or non supplemented diet $(8.5 \mathrm{~g} / \mathrm{kg}$ ) (Moran and Bilgili, 1990).

According to Sibbald and Wolynetz (1987) the dietary lysine concentration did not modify energy retention but altered the partition: with the addition of lysine in the diet, energy retained as lipids decreased whereas the energy retained as protein increased.

However, in our experimental conditions, fatness in abdominal cavity cannot be reduced below a certain limit, since an excess of lysine in the diet ( $>1 \mathrm{~g} / \mathrm{kg}$ ) did not modify the abdominal fat proportion.
The reduction in fatness observed in this experiment could be explained by a decrease in lipogenesis, due to an alteration of malic enzyme activity. Thus, a single essential amino acid could participate in the reduction of fatness (observed by Bartov, 1979; Jackson et al, 1982; Pesti and Fletcher, 1984; Grisoni et al, 1990) or in the decrease of lipogenesis (Yeh and Leveille, 1969; Tanaka et al, 1983; Rosebrough and Steele, 1985a, b) when the dietary protein level increased. Other amino acids, as for example methionine, could take part in this effect and in the regulation of lipogenesis in broilers. Indeed, supplementation with methionine in the finisher phase using a diet containg $180 \mathrm{~g} / \mathrm{kg}$ protein involved a reduction in fatness without modifying the growth rate (Larbier and Leclercq, 1980).

In conclusion, our results show that the calculated lysine requirement of chickens for growth rate during the finisher phase is largely correct (INRA, 1984; Larbier, 1985; AEC, 1989). However, this requirement could be raised to minimize the abdominal fat proportion and then to improve carcass quality. The lysine supplied in a deficient diet could participate in a reduction of lipogenesis and fatness. But this effect is not amplified by an excess of lysine in the diet.

\section{REFERENCES}

AEC (1976) Taux protéiques bas. In: Études Poulet de Chair (2) Poultry. Rhône-Poulenc Anim Nutr, 03600 Commentry, France, No 241

AEC (1989) Recommandations Pour la Nutrition Animale. Rhône-Poulenc Animal Nutrition, Anthony, France, 5th edn

Bartov I (1979) Nutritional factors affecting quantity and quality of carcass fat in chickens. Fed Proc 38, 2627-2630

Bougon M, Protais J, L'hospitalier R (1985) Variations de la composition des poulets avec dif- 
férents facteurs nutritionnels. Bull Inf Stat Exp Avic Ploufragan 25, 159-169

Chang GG, Hsu RY (1977) Mechanism of pigeon liver malic enzyme. Kinetics, specificity and half-site stoichiometry of the alkylation of a cysteinyl residue by the substrate-inhibitor bromopyruvate. Biochemistry 16(2), 311-320

D'Mello JPF, Lewis D (1970) Amino acid interactions in chick nutrition. 3. Interdependence in amino acid requirements. Br Poult Sci 11 , 367-385

Duncan DB (1955) Multiple range and multiple tests. Biometrics 11, 1-42

Ehinger F, Seeman $G$ (1982) Einfluss von Futter, Alter und Geschlecht auf die Mastleistung und die Schlachtkörperqualität von Broilern verschiedener Herkunft. 2. Mitteitung: Verfettungsgrad. Arch Geflügelk 46, 177-188

Fisher $C$ (1984) Fat deposition in broilers. In: Fats in Animal Nutrition (Wiseman J, ed) Butterworths, London 437-470

Grisoni ML, Larbier M, Uzu G, Geraert PA (1990) Effect of dietary protein level on lipid deposition in broilers during the finishing period. Ann Zootech 39, 179-186

INRA (1984) Alimentation des Animaux Monogastriques: Porc, Lapin, Volailles. INRA, Paris, $282 \mathrm{p}$

Jackson S, Summers JD, Leeson S (1982) Effect of dietary protein and energy on broiler carcass composition and efficient of nutrient utilization. Poult Sci61, 2224-2240

Larbier M, Leclercq B (1980) Le besoin en méthionine du poulet de chair en finition. Ann Zootech 29, 401-407

Larbier $M$ (1985) Protein and lysine requirement of broilers: L-lysine $\mathrm{HCl}$ efficacy in low protein diets. In: Proc 5th Eur Symp Poult Sci (World Poult Sci Assoc, ed) Maale Hachamisha, Israel, 215-216

Leenstra FR (1986) Effect of age, sex, cenotype and environment on fat deposition in broiler chickens. A review. World Poult Sci J 2(1), 12-25

Leveille GA, Romsos DR, Yeh YY, O'Hea EK (1975) Lipid biosynthesis in the chick. A consideration of site of synthesis, influence of diet and possible regulatory mechanisms. Poult Sci 54, 1075-1093

Moran ET Jr, Bilgili SF (1990) Processing losses, carcass quality and meat yields of broiler chickens receiving diets marginally deficient to adequate in lysine, prior to marketing. Poult Sci 69, 702-710

Nir I (1984) Factors influencing excessive fat deposition in meat poultry. In: Proc 17th World Poult Congr Helsinki (WPSA, ed) Finnish Branch, 53-56

Nir I, Nitsan Z, Keren-Zvi S (1988) Fat deposition in birds. In: Leanness of Domestic Birds Genetic, Metabolic and Hormonal Aspects (Leclercq B, Whitehead CC, eds) Butterworths, London, ch 15, 141-174

Ochoa $S$ (1955) Malic enzyme. In: Methods in Enzymology (Colowick SP, Kaplan NO, eds) Academic Press, NY, vol 1, 739-753

Pesti GM, Fletcher DL (1984) The response of male broiler chickens to diets with various protein contents during the grower and the finisher phases. Br Poult Sci 25, 415-423

Ricard FH (1983) Mesure de l'état d'engraissement chez le poulet. Variabilité d'origine biologique. In: Qualité des Viandes de Volaille. Vith Symp, 17-20 May 1983 (Lahellec C, Ricard FH, Colin P, eds) Stat Exp Avic Ploufragan, 49-68

Rosebrough RW, Steele NC (1985a) Energy and protein relationships in the broiler: 1 . Effect of protein levels and feeding regimens on growth, body composition and in vitro lipogenesis of broiler chicks. Poultr Sci 64, 119126

Rosebrough RW, Steele NC (1985b) Energy and protein relations in the broiler chicken: 2 . Effect of varied protein and constant carbohydrate levels on body composition and lipid metabolism. Growth 49, 479-489

Scheelle CW, Van Schagen PJW, Ten Have HGM (1981) Abdominal and total fat content of 3 broiler strains at two ages affected by nutritional factors. In: Quality of Poultry Meat (Mulder RWAW, Scheele CW, Veerkamp $\mathrm{CH}$, eds) Spelderholt Institute for Poultry Research, Beekbergen, 397-407

Sibbald IR, Wolynetz MS (1986) Effects of dietary lysine and feed intake on energy utilization and tissue synthesis by broiler chicks. Poult Sci 65, 98-105

Sibbald IR, Wolynetz MS (1987) Effects of dietary fat level and lysine/energy ratio on energy utilization and tissue synthesis by broiler chicks. Poult Sci 66, 1788-1797 
Tanaka K, Ohtani S, Shigeno K (1983) Effect of increasing dietary energy on hepatic lipogenesis in growing chicks. 2. Increasing energy by fat or protein supplementation. Poult Sci $62,452-458$
Uzu G (1982) Limit of reduction of the protein level in broiler feeds. Poult Sci 61, 1557

Yeh YY, Leveille GA (1969) Effect of dietary protein on hepatic lipogenesis in the growing chicks. J Nutr 98, 356-366 